\title{
Correction to: Concerns About ABA-Based Intervention: An Evaluation and Recommendations
}

\author{
Justin B. Leaf ${ }^{1}\left(\mathbb{D}\right.$. Joseph H. Cihon ${ }^{1} \cdot$ Ronald Leaf $^{1} \cdot$ John McEachin $^{1} \cdot$ Nicholas Liu $^{2} \cdot$ Noah Russell $^{1} \cdot$ Lorri Unumb $^{3}$. \\ Sydney Shapiro ${ }^{3}$. Dara Khosrowshahi ${ }^{3}$
}

Published online: 20 July 2021

๑) Springer Science+Business Media, LLC, part of Springer Nature 2021

\section{Correction to: J Autism Dev Disord (2021) https://doi.org/10.1007/s10803-021-05137-y}

The original version of the manuscript (i.e., Leaf et al., 2021) was published with a Green and Striefel (1988) reference by mistake. This reference should have instead been Favell, McGimsey, and Jones (1978). The original version of the manuscript was published declaring no conflicts of interest. It should be noted that ABA research, trainings, and services are provided by authors J. Leaf, Cihon, R. Leaf, McEachin, and Russell. Shapiro serves as board member of Autism Partenrship Foundation and J. Leaf. serves on several Editorial Boards, including JADD.

The original article can be found online at https://doi.org/10.1007/ s10803-021-05137-y.

Justin B. Leaf

Jblautpar@aol.com

Joseph H. Cihon

jcihon@autismpartnership.com

Ronald Leaf

Rlautpar@aol.com

John McEachin

Jmautpar@aol.com

Nicholas Liu

nliu1@uchicago.edu

Noah Russell noahrussell@verizon.net

\section{References}

Favell, J. E., McGimsey, J. F., \& Jones, M. L. (1978). The use of physical restraint in the treatment of self-injury and as positive reinforcement. Journal of Applied Behavior Analysis, 11(2), 225-241. https://doi.org/10.1901/jaba.1978.11-225

Leaf, J. B., Cihon, J. H., Leaf, R., McEachin, J., Liu, N., Russell, N., Unumb, L., Shapiro, S., \& Khosrowshahi, D. (2021). Concerns about ABA-Based intervention: An evaluation and recommendations. Journal of Autism and Developmental Disorders. Advance online publication. https://doi.org/10.1007/s10803-021-05137-y

Publisher's Note Springer Nature remains neutral with regard to jurisdictional claims in published maps and institutional affiliations.

\author{
Lorri Unumb \\ lunumb@casproviders.org \\ Sydney Shapiro \\ HTavakol@autismpartnershipfoundation.org \\ Dara Khosrowshahi \\ info@autismpartnershipfoundation.org \\ 1 Autism Partnership Foundation, 200 Marina Drive, \\ Seal Beach, CA 90740, USA \\ 2 University of California, Santa Barbara, CA, USA \\ 3 Parent, Napa, CA, USA
}

